\title{
Chapter 21 \\ The Extent and Effectiveness of Alien Plant Control Projects in South Africa
}

\author{
Brian W. van Wilgen (D), John R. Wilson (D), Andrew Wannenburgh (D), \\ and Llewellyn C. Foxcroft $(\mathrm{D}$
}

\begin{abstract}
Since 1995, the South African government has spent at least ZAR 15 billion (unadjusted for inflation; approximately USD1 billion) on alien plant control operations across South Africa. The amount spent per year has risen exponentially since 2010, and in 2019 annual spending is around ZAR 2 billion per year. Based on a small (but growing) number of case studies that have assessed management effectiveness, it is clear that the cover of invasive alien plants has been reduced in some localised areas, but continues to grow in others. A number of factors contribute to success, but the effort and resources required for successful control appear to be routinely under-estimated, with actual costs between 1.5 and 8.6 times higher than initial budget estimates. Currently, therefore, control measures (other than biological control) have largely failed to check invasions at a national scale, and there have been no documented eradications of plant invasions from continental South Africa. We argue that control can be considerably improved by effective prioritisation, goal-setting and planning; monitoring of outcomes rather than of inputs;
\end{abstract}

B. W. van Wilgen $(\bowtie)$

Centre for Invasion Biology, Department of Botany and Zoology, Stellenbosch University, Stellenbosch, South Africa

e-mail: bvanwilgen@sun.ac.za

J. R. Wilson

Centre for Invasion Biology, Department of Botany and Zoology, Stellenbosch University, Stellenbosch, South Africa

South African National Biodiversity Institute, Kirstenbosch Research Centre, Cape Town, South Africa
A. Wannenburgh
Department of Environment, Forestry and Fisheries, Cape Town, South Africa
L. C. Foxcroft
Centre for Invasion Biology, Department of Botany and Zoology, Stellenbosch University, Stellenbosch, South Africa
Conservation Services, South African National Parks, Skukuza, South Africa 
ensuring that the existence of multiple goals does not lead to confusion over priorities; developing methods to reduce the under-estimation of the costs of control; adherence to best practices and standards; simplifying the currently complex contracting and employment models; and using a variety of methods to resolve or reduce conflicts over species that have commercial or other value, but cause significant environmental damage. Addressing these challenges will be difficult, but would be essential if plant invasions in South Africa are to be brought under control.

\subsection{Introduction}

Attempts to control invasive alien plants have a long history in South Africa. While we do not have detailed knowledge of early control efforts, regulations relating to invasive plant management date back to 1861 (see Lukey and Hall 2020, Chap. 18). The first biological control agents were introduced over 100 years ago (Moran et al. 2013). The government made attempts to control pines (Pinus species), gums (Eucalyptus species) and hakeas (Hakea species) in grassland and fynbos areas near Makhanda (Grahamstown) as early as the 1930s (Macdonald 2004). In 1943, operations were introduced to control invasive alien pines, wattles (Australian Acacia species) and gums in the Cape of Good Hope Nature Reserve on the Cape Peninsula (Macdonald et al. 1989). Attempts to control invasive alien plants in the Kruger National Park began in the 1950s (Foxcroft and Freitag-Ronaldson 2007). In 1968, legislation was enacted and an eradication programme initiated against Solanum elaeagnifolium (Satansbos), although eradication was never achieved (Wilson et al. 2013). In 1976, the Department of Forestry scaled up its efforts to control invasive alien plants in the mountain catchment areas in the Western Cape (Fugler 1983; Fenn 1980), but after a decade the programme fell behind schedule, and essentially came to a halt when the responsibility for managing catchment areas was transferred to the provinces in the late 1980s (van Wilgen and Wannenburgh 2016). In 1995, efforts to control invasive alien plants across the whole country were started afresh under the auspices of the Working for Water (WfW) Programme. This public works programme has the dual goals of controlling invasive alien plants while at the same time creating employment and development opportunities for disadvantaged people in rural areas (van Wilgen and Wannenburgh 2016). This chapter reviews the extent to which projects dealing with terrestrial plant invaders have been implemented across the country, and their costs and effectiveness. Chapter 4 (Hill et al. 2020a) discusses progress and challenges relating to the management of aquatic plant invaders. 


\subsection{Alien Plant Control Projects}

Many conservation agencies at national and provincial level, private landowners, volunteer "hack" groups, and NGOs have implemented alien plant control projects (Fenn 1980; Attwell 1985; Macdonald et al. 1985; van Wilgen et al. 2017; van Rensburg et al. 2017). However, monitoring data for these efforts were either not available to us, or were never collected in the first place. This section therefore provides a brief summary of the extent of alien plant control projects funded by the WfW programme between 1995 and 2017, both because data are available, and because WfW has provided the bulk of funding for alien plant control projects over the past two decades.

Since 1995, WfW has spent ZAR 15 billion (unadjusted for inflation) on alien plant control operations across South Africa. The amount spent per year has risen exponentially since 2010, reaching around ZAR 2 billion per year in 2017 (Fig. 21.1a). During this time, WfW has cleared an average of about 200,000 condensed ha (Fig. 21.1c) per year, and conducted follow-up operations on about 600,000 ha per year (cleared areas are subjected to an average of three follow-up operations over time). The apparent decrease in area treated since 2014 is due to a relaxation of the requirement to record areas treated. This essentially means that recent figures are underestimates. In terms of the species targeted, wattles received more than three times the funding (ZAR 3.5 billion) than any other taxon (Table 21.1). The other groups on which large amounts have been spent include Lantana camara (Lantana), trees in the genera Prosopis and Eucalyptus, and Chromolaena odorata (Triffid Weed) (Table 21.1). WfW has dual goals, which require it to create employment and to clear invasive alien plants (van Wilgen and Wannenburgh 2016); the programme has created between 2000 and 23,000 fulltime equivalent jobs per year.

Alien plant control operations funded by WfW are carried out by implementing agents who often operate on adjacent land parcels owned or managed by different agencies. Plant invasions, however, do not respect jurisdictional boundaries. To gain control over invasions in any given area, it would therefore be necessary for neighbouring landowners to collaborate closely with each other, and to co-ordinate control efforts, which brings additional challenges. Box 21.1 profiles case studies where alien plants are managed in large areas across several jurisdictions to illustrate challenges and achievements. 

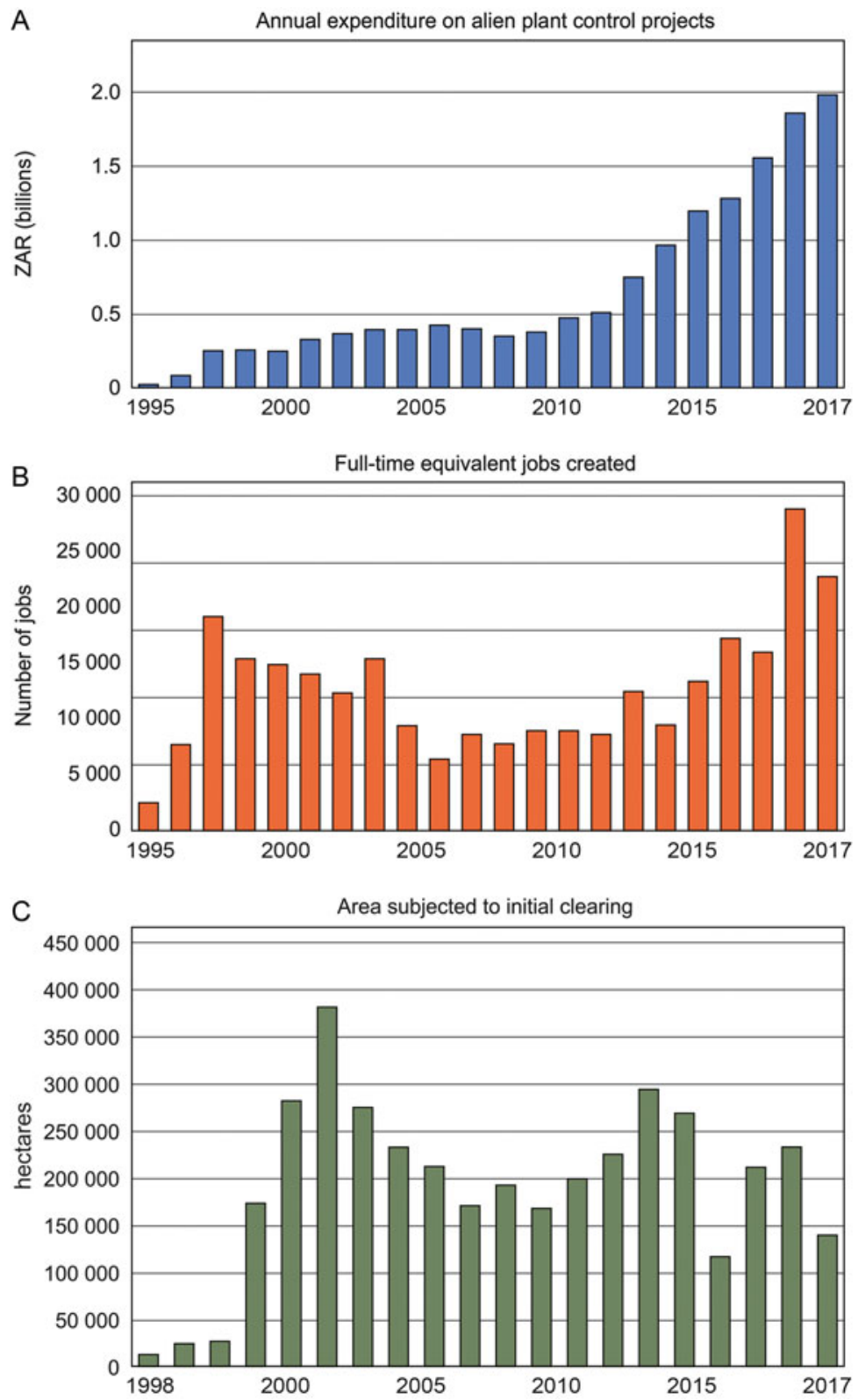

Fig. 21.1 The contribution of the Working for Water programme to alien plant control in South African in terms of: (a) the amount of money invested (ZAR unadjusted for inflation); (b) the number of full-time equivalent jobs created. This number only includes jobs created for previously unemployed people as part of poverty alleviation efforts; (c) the area treated per annum in condensed ha (see Table 21.1 for a definition of condensed ha). Note that the apparent decrease in area treated between 2013 and 2014 is due to a relaxation of the requirement to record areas treated. Data sourced from Working for Water Information Management System 


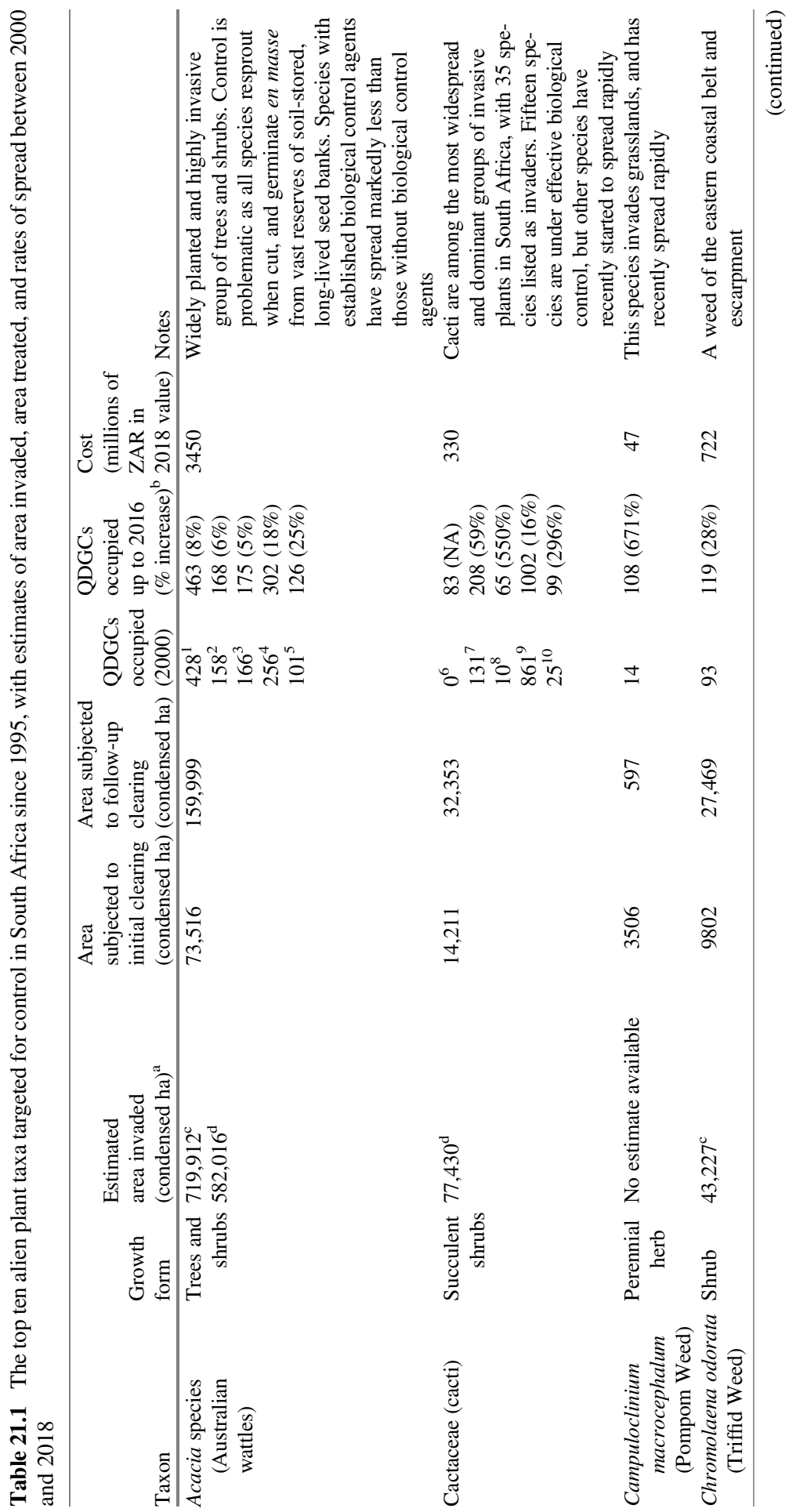




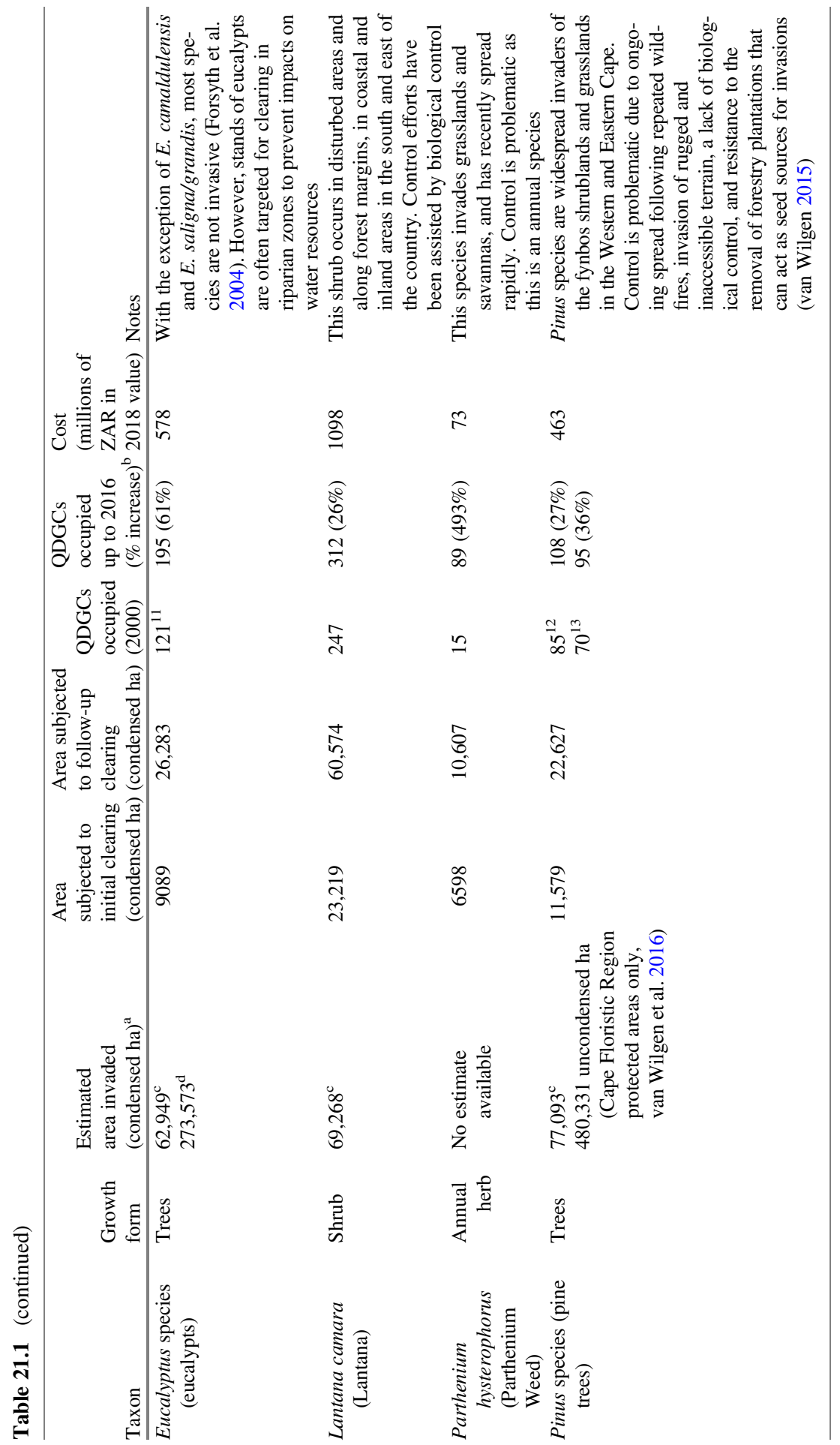




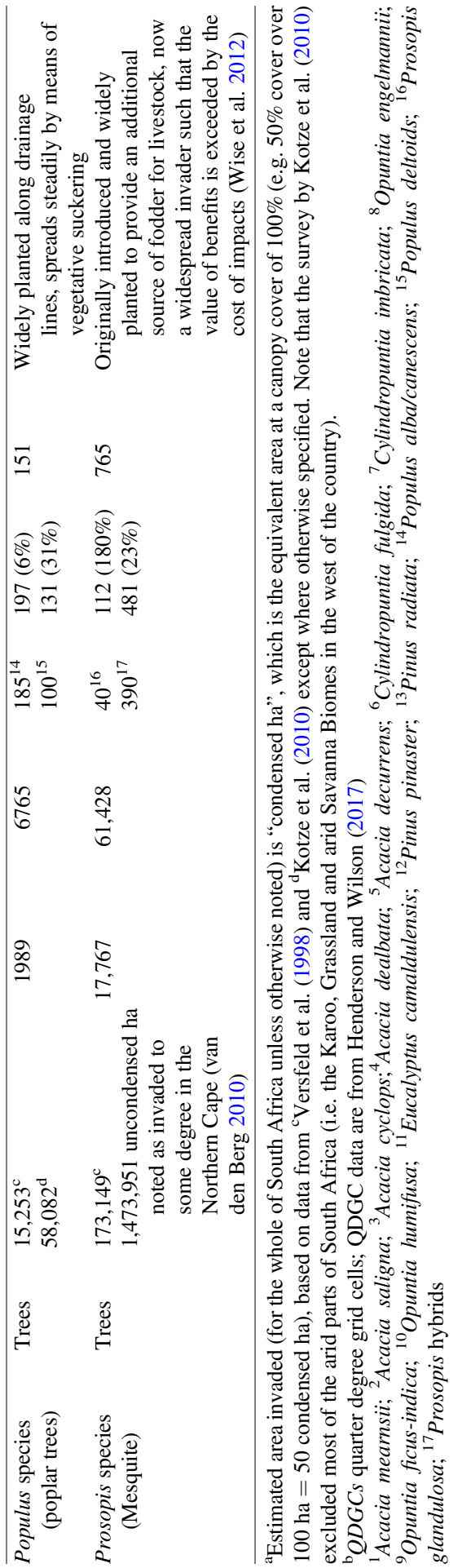




\section{Box 21.1 Co-ordinating Alien Plant Control Across Jurisdictions: Three examples from Biosphere Reserves in South Africa}

Implementing effective alien plant control projects is difficult enough on individual protected areas or farms, but the complexity increases exponentially when an invasion occurs across multiple land parcels, owned or managed by different individuals or organisations, each with different purposes and levels of capacity. For the management of invasive alien plants to be effective, collaboration across different land parcels is needed. Biosphere reserves are a good model for how this can be achieved. Biosphere reserves are areas of terrestrial and coastal ecosystems that are internationally recognised within the framework of the United Nations Education, Scientific and Cultural Organisation's (UNESCO's) Man and Biosphere programme. Biosphere Reserves have core, buffer and transition zones that cater for strict conservation, limited sound ecological use, and ecologically-friendly development respectively. South Africa has eight Biosphere Reserves, and within some of these there have been attempts to co-ordinate alien plant control projects. An examination of three of these Biosphere Reserves (table below) reveals some common features:

- It is essential to have a dedicated and committed co-ordinator to provide direction and continuity;

- The disbursement of funds across multiple organisations increases the levels of bureaucracy, significantly slowing progress;

- There are no examples of comprehensive control plans that cover entire biosphere reserves, although there are attempts to foster collaboration;

- The funds required to address the problem over large areas are typically inadequate;

- The relative importance of different species differs according to land use, resulting in differences in priority across the area being managed; and

- Private landowners are obliged in terms of law to control invasive alien species, but the capacity to enforce the regulations is inadequate.

- The bulk of the funding comes from the government's Working for Water (WfW) programme. 


\begin{tabular}{|c|c|c|c|}
\hline $\begin{array}{l}\text { Area and managing } \\
\text { agencies }\end{array}$ & Features & $\begin{array}{l}\text { Funding and } \\
\text { planning }\end{array}$ & $\begin{array}{l}\text { Achievements and } \\
\text { challenges }\end{array}$ \\
\hline $\begin{array}{l}\text { Kogelberg Biosphere } \\
\text { Reserve, Western } \\
\text { Cape. } \\
\text { Managed by: } \\
\text { - CapeNature } \\
\text { (provincial con- } \\
\text { servation agency) } \\
\text { - Two municipal- } \\
\text { ities (Cape Town } \\
\text { and Overstrand) } \\
\text { - Private } \\
\text { landowners }\end{array}$ & $\begin{array}{l}\text { The area covers } \\
\text { 103,629 ha in the } \\
\text { Fynbos Biome, } \\
\text { Western Cape, } \\
\text { including a core } \\
\text { protected area } \\
\text { (Kogelberg } \\
\text { Nature Reserve), } \\
\text { commercial for- } \\
\text { estry plantations } \\
\text { with alien trees, } \\
\text { and residential } \\
\text { townships. The } \\
\text { area is invaded by } \\
\text { numerous alien } \\
\text { plant species, } \\
\text { mainly trees and } \\
\text { shrubs in the } \\
\text { genera Pinus, } \\
\text { Acacia and } \\
\text { Hakea. }\end{array}$ & $\begin{array}{l}\text { The bulk of the } \\
\text { funding comes } \\
\text { from the } \\
\text { government's } \\
\text { Working for } \\
\text { Water } \\
\text { programme } \\
\text { Municipalities } \\
\text { contribute } \\
\text { some funding } \\
\text { additional to } \\
\text { WfW. Several } \\
\text { private land- } \\
\text { owners also } \\
\text { contribute, but } \\
\text { many do not } \\
\text { There is a high- } \\
\text { level alien plant } \\
\text { control plan for } \\
\text { the protected } \\
\text { core area, and } \\
\text { some groups of } \\
\text { private land- } \\
\text { owners have } \\
\text { developed sep- } \\
\text { arate plans for } \\
\text { their own land. }\end{array}$ & $\begin{array}{l}\text { Plant invasions in the core } \\
\text { area have been } \\
\text { brought down to a } \\
\text { maintenance level; } \\
\text { invasions on privately } \\
\text { owned land remain a } \\
\text { problem, and the } \\
\text { cleared core area is at } \\
\text { risk of re-invasion as a } \\
\text { result } \\
\text { Agreement has been } \\
\text { reached between } \\
\text { CapeNature and } \\
\text { owners of pine forestry } \\
\text { plantations for the sys- } \\
\text { tematic removal of } \\
\text { plantations } \\
\text { Uncontrolled wildfires } \\
\text { frequently disrupt } \\
\text { clearing operations, } \\
\text { spreading the invasive } \\
\text { plants } \\
\text { Although some } \\
\text { funding is available, it } \\
\text { is insufficient to ade- } \\
\text { quately address the } \\
\text { problem. }\end{array}$ \\
\hline $\begin{array}{l}\text { Vhembe Biosphere } \\
\text { Reserve, Lim- } \\
\text { popo. } \\
\text { South African } \\
\text { National Parks } \\
\text { and provincial } \\
\text { agencies are } \\
\text { responsible for } \\
\text { protected areas, } \\
\text { but much of the } \\
3 \text { million ha of } \\
\text { privately owned } \\
\text { and communal } \\
\text { land is not } \\
\text { managed }\end{array}$ & $\begin{array}{l}\text { The area covers } \sim 3.7 \\
\text { million ha, with } \\
\text { eight core } \\
\text { protected areas } \\
\text { totalling } \\
\text { 460,000 ha. It } \\
\text { includes two } \\
\text { national parks } \\
\text { (northern region } \\
\text { of Kruger } \\
\text { National Park, } \\
\text { and } \\
\text { Mapungubwe } \\
\text { National Park), } \\
\text { and six provincial } \\
\text { protected areas. } \\
\text { There are over } \\
120 \text { invasive } \\
\text { alien plant spe- } \\
\text { cies in the area, }\end{array}$ & $\begin{array}{l}\text { The bulk of the } \\
\text { funding comes } \\
\text { from the gov- } \\
\text { ernment's } \\
\text { Working for } \\
\text { Water } \\
\text { programme } \\
\text { Planning is } \\
\text { largely carried } \\
\text { out indepen- } \\
\text { dently by land- } \\
\text { owners, with } \\
\text { some coordi- } \\
\text { nated planning } \\
\text { between adja- } \\
\text { cent agencies }\end{array}$ & $\begin{array}{l}\text { An Invasive Species } \\
\text { Working and Network } \\
\text { Group has been } \\
\text { established for the } \\
\text { Biosphere Reserve, but } \\
\text { it has proved challeng- } \\
\text { ing to find an effective } \\
\text { and dedicated co-ordi- } \\
\text { nator } \\
\text { Projects have been ini- } \\
\text { tiated to map the dis- } \\
\text { tribution of priority } \\
\text { invasive alien species } \\
\text { Species task teams } \\
\text { have been established } \\
\text { to co-ordinate alien } \\
\text { plant control at a } \\
\text { catchment or individ- } \\
\text { ual protected area level } \\
\text { The complexity of }\end{array}$ \\
\hline
\end{tabular}


the most impor-

tant of which are

Lantana camara

(Lantana),

Chromolaena

odorata (Triffid

Weed) and Senna

species in the

lower catchment.

Trees in the gen-

era Acacia and

Eucalyptus are

prominent in the

upper

Soutpansberg

Kruger 2 Canyons

Biosphere

Reserve, Lim-

popo and $\mathrm{Mpu}$ -

malanga.

South African

National Parks, provincial conservation agencies, private conservation areas, municipalities, NGOs, and traditional leaders and communities. Alien plant control efforts across 21 organisations are monitored by a government environmental monitoring programme in an attempt to co-ordinate efforts
The area covers $\sim 2.5$ The bulk of the million ha, with a core area of $\sim 898,300$ ha of protected areas, including the central region of Kruger National Park, ten provincial protected areas, and large privately owned game farms ( 400,000 ha). A wide variety of alien plants are present, the most important of which are

Parthenium hysterophorus

(Parthenium

Weed) in lowerlying areas, and Melia azedarach (Syringa), and trees in the genera Pinus, Eucalyptus and Acacia in the upper catchments. funding comes from the government's Working for Water programme SANParks and Kruger 2 Canyons collaborate to guide work in priority areas, but there are no formal management plans. Other stakeholders are kept informed through several committees.

managing plant invasions over such a large area with varied land uses precludes effective coordination. However, coordinated communication at the biosphere scale, and cooperative planning at smaller scale, may overcome this

Environmental monitors have been appointed to collect alien plant distribution data, for use by managers across different areas and projects

A semi-formal supports the sharing of information Differing objectives (e.g. water conservation, biodiversity conservation, livestock production, and agriculture) result in different invasive species receiving priority in different areas. Buffer areas have been designated to allow close neighbours to align their objectives and efforts. 


\subsection{Alien Plant Eradication Projects}

The Working for Water programme (WfW) explicitly took an area-based, as opposed to a species-based, approach to management (see Faulkner et al. 2020, Chap. 12, for a discussion on pathway-based approaches). Invaded areas were demarcated, estimates of the overall density of all alien plants in those areas were made, and contracts issued to clear all the alien plants in the specified areas. Classical biological control aside, individual species were not explicitly targeted. To address this gap, in 2008, the South African National Biodiversity Institute (SANBI) was contracted by WfW to develop species-specific control programmes focusing on alien plant species that were not yet widespread invaders (Wilson et al. 2013). Over time, this mandate has narrowed so that the focus of control efforts is on species where the possibility of national-scale eradication has not been ruled out (see Sect. 21.6 for a discussion of species-specific management programmes where the goal is not eradication).

There have been several documented plant eradication attempts in continental South Africa, all initiated by the government, but none of which succeeded (cf. work on the sub-Antarctic Islands, Greve et al. 2020, Chap. 8). Intensive programmes were initiated in the early 1960s to remove Alhagi camelorum (Camel Thorn) from irrigation schemes. However, the systemic herbicides available at the time were ineffective for dealing with the extensive underground root systems (Erasmus and Viljoen 1993; Jooste 1965). In 1968 an eradication programme was initiated against Solanum elaeagnifolium (Satansbos) (Wasermann et al. 1988). Despite some local successes, by 1972 the eradication campaign was cancelled; failure was ascribed to inadequate biological knowledge, ineffective herbicides and application techniques, and a lack of cooperation from many farmers. The most extensive eradication campaign in South Africa was against Opuntia aurantiaca (Jointed Cactus) (Moran and Annecke 1979), but despite significant governmental support, apparently not a single farm was fully cleared.

These efforts focussed on alien plants that were already widespread in the country, and basic requirements to achieve eradication were not always in place, e.g. no new immigration of propagules, all populations delimited, sufficient resources available to complete eradication, and adequate monitoring and evaluation in place (Wilson et al. 2017).

There are 42 alien plant species listed as Category 1a in South Africa's Alien \& Invasive Species Regulations, published in 2014 under the National Environmental: Biodiversity Act (NEM:BA, Act 10 of 2004) (i.e. deemed as nation-wide eradication targets). On investigation, several of these species have been found to be present at many sites across the country (e.g. Iris pseudacorus (Yellow Flag) (Jaca and Mkhize 2015), and Furcraea foetida (Mauritian Hemp), although the formal process of documenting the evidence and transfer of these species to more appropriate management categories has not been completed yet (see Chap. 20; Kumschick et al. 2020). Several of the Category 1a species [Cabomba caroliniana, (Cabomba) and Euphorbia esula (Leafy Spurge)] have not been found again, and might simply not be in the country, while others are not known to have become invasive and were listed for precautionary purposes (Henderson and Wilson 2017). Several of the species are found 
in private gardens [e.g. Triplaris americana (Ant Tree)]. While this does not preclude eventual eradication, it complicates both control efforts and our ability to declare a species eradicated. A few Cactaceae species have (or will likely in future have) effective biocontrol agents, such that nation-wide eradication would probably not be required for adequate control to be effected. Consequently, only around a third of the species listed in Category 1a are still the focus of on-going eradication efforts. By contrast, many other taxa that are not yet listed in the regulations have been identified as eradication targets and are subject to control efforts [e.g. Acacia viscidula (Sticky Wattle), and Melaleuca parvistaminea (Rough-barked Honey Myrtle) (Magona et al. 2018; Jacobs et al. 2014)].

The mismatch between legal status and feasibility of eradication discussed above highlights the need to set eradication as the management goal only once a formal detailed assessment of eradication feasibility has been conducted. Such assessments require investment in delimitation and pilot control measures (Wilson et al. 2017). It is also clear that there is a substantial invasion debt in the country (Rouget et al. 2016) — many alien plants have only naturalised or invaded a few sites, and there are likely to be many that are still to be detected.

In the decade that the SANBI programme has been active, no alien plant species had been formally declared as eradicated. The project closest to achieving eradication is probably that against Spartina alterniflora (Smooth Cordgrass), a grass invading the Knysna estuary in the Western Cape. However, the conditions under which eradication can be declared have not been specified, nor is it clear why the plant was introduced in the first place, so the possibility of reintroduction has not been ruled out (Riddin et al. 2016). Detailed point patterns have been produced for a number of species (Wilson et al. 2013), and insights have been gained in terms of efforts to delimit populations (Jacobs et al. 2014), produce risk maps (Kaplan et al. 2014), estimate the costs of eradication (Moore et al. 2011), and the continuing need for morphological and molecular taxonomy (Magona et al. 2018; Jacobs et al. 2017).

The SANBI programme has funded postgraduate students to work on particular species or taxa, and produced an increasing number of published analyses of risk analyses, impact assessments, and estimates of eradication feasibility (Kumschick et al. 2020). However, the programme has suffered from similar issues to other projects funded under the WfW umbrella. The onus has been to report on input indicators (e.g. person days of employment), and few or no data are routinely collected on output indicators (e.g. the number of plants present). When assessed against the requirements set by the National Status Report on Biological Invasions (van Wilgen and Wilson 2018), the project planning was evaluated as being inadequate across the board. These are solvable issues, but will require a shift in approach to ensure that dedicated teams focus on specific targets year on year, that data are collected, and that monitoring data feed back into decision-making both at a project level and as input to the regulatory changes. If the global best practices regarding alien plant incursion response are applied (e.g. Wilson et al. 2017), then we can expect to see an increasing number of declared alien plant eradications in the next decade. For some taxa, particularly those with long-lived seed-banks (Zenni et al. 2009; Wilson et al. 2011), eradication might only be achieved far in the future, but it is feasible given persistence and effective monitoring. 


\subsection{Management Plans for Invasive Species}

South Africa's National Environmental Management: Biodiversity Act (NEM:BA), Alien \& Invasive Species (A\&IS) Regulations, published in 2014, state that "if an Invasive Species Management Programme has been developed in terms of section 75 (4) of the Act, a person must control the listed invasive species in accordance with such programme". In many cases, the need for species-specific management programmes is clear, even for species where eradication is not feasible, but neither the Act nor the Regulations, provide guidance on which of the listed invasive species should be the subject of such a programme. The development of national-level, species-specific programmes for all listed species would be extremely onerous, but there has been little to no progress even on priority species. Species-specific strategies have been developed only for Parthenium hysterophorus (Parthenium Weed), and Campuloclinium macrocephalum (Pompom Weed) (Le Maitre et al. 2015; Terblanche et al. 2016; see also Table 21.1). These strategies recommended different management approaches for different administrative areas depending on the stage of invasion. In addition, two genus-level strategies [for Australian Acacia species and Prosopis (van Wilgen et al. 2011; Shackleton et al. 2017)], and one family-level strategy (for Cactaceae, Kaplan et al. 2017) have been developed.

None of these strategies has been formally adopted to date, and no entities have been established, as provided for in law, to co-ordinate and implement them (though the aim of the National Cactus Working Group is to facilitate the implementation of the Cactaceae strategy; Kaplan et al. 2017).

\subsection{Management Plans for Invaded Areas}

The successful implementation of invasive alien plant control projects relies on, among other things, careful planning that sets realistic goals, monitoring of progress towards those goals, and adapting management as new information comes to light. In South Africa, there are a number of statutory requirements to develop such plans. The management authorities of protected areas, and all other organs of state in all spheres of government are required in terms of the NEM:BA A\&IS Regulations to prepare invasive alien species control plans; and in terms of the National Environmental Management: Protected Areas Act (Act 57 of 2003, NEM:PAA), the management authorities of all protected areas must submit a management plan for the protected area for ministerial approval. In turn, plans require accurate information on the extent and abundance of invasive species, so that the resources required to control them can be reliably estimated. These requirements have not been adhered to in practice, however. In terms of the NEM:BA requirement, submitted control plans covered only about $4 \%$ of the country, mainly in the Western Cape, and almost all of the plans failed to meet the required criteria (van Wilgen and Wilson 2018). Both the relatively small number of plans, and the inadequacy of many plans, was attributed to a lack of capacity or 
expertise within many organs of state (van Wilgen and Wilson 2018). Furthermore, while most protected areas have prepared management plans as required by NEM: PAA, the sections of these plans that deal with alien plant control are typically highlevel, long-term statements of intent, and these have not been effectively carried forward into the more detailed medium to short-term plans that would be necessary for guiding control operations (van Wilgen et al. 2017).

Creating accurate maps of the distribution and abundance of alien plant invasions as a basis for realistic planning has also proved challenging up to now (Richardson et al. 2020, Chap. 3). At a national scale, there have been at least three attempts to map the extent of the problem. In 1993, the Council for Scientific and Industrial Research mapped invasive alien plants in South Africa, with the goal of estimating their impact at a national scale (Le Maitre et al. 2000). The mapping techniques used were coarse due to the paucity of reliable data, but a map at a 1:250,000 scale was produced, based primarily on the local knowledge of natural resource experts from across South Africa. The project estimated that invasive plants occupied 10.1 million ha $(6.82 \%$ of South Africa and Lesotho). The longest-running project aimed at recording information on the national extent of alien plants is the Southern African Plant Invaders Atlas (SAPIA), which was initiated in 1994 (Henderson 2007). As of May 2016, SAPIA had over 87,000 geo-referenced records for 773 alien plant taxa that are present outside of cultivation in southern Africa, making it the most extensive source of information on the distribution of invasive plants in the region (see Richardson et al. 2020). In 2008, the Department of Environmental Affairs commissioned the Agricultural Research Council to develop and implement a repeatable sampling protocol to track trends in alien plant distribution and density across half of the country. This project has run for more than a decade, and has mapped the distribution of 27 alien plant taxa (species in the genera Pinus, Eucalyptus and some Australian Acacia species were mapped collectively). The project is ongoing, but no adequate description of the sampling methodology has been published to date, nor have any peer-reviewed papers that present the findings been published.

At finer scales, relatively detailed maps of the extent of invasion have been developed for some areas, mostly protected areas [e.g. Foxcroft et al. $(2004,2009)$ for Kruger National Park; Cheney et al. (2018) for Table Mountain National Park; and van Wilgen et al. (2016) for protected areas in the Cape Floristic region]. Cheney et al. (2018) compiled a map of invasive alien plants derived from fine-scale systematic sampling of the entire Table Mountain National Park (26,500 ha), and compared this to two other datasets in use for planning and management. They found that management datasets overestimated species cover by orders of magnitude, and that this resulted in questionable allocations of funding. They concluded that "contrary to perception, fine-scale surveys are a cost-effective way to inform long-term monitoring programmes and improve programme effectiveness". In addition, where plans are developed, they are not always followed (Kraaij et al. 2017). It appears, thus, that the level of planning for alien plant control in South Africa falls substantially short both of what is required by law and what is necessary for management to be effective. 


\subsection{National-Scale or Species-Specific Assessments of Management Effectiveness}

The most comprehensive national-scale assessment of management efficacy at a species level to date (Henderson and Wilson 2017) was based on the Southern African Plant Invaders Atlas (SAPIA). The 773 alien plant taxa recorded in SAPIA was an increase of 172 taxa over the last assessment in 2006 (Henderson and Wilson 2017). Between 2000 and 2016 there was also an approximately 50\% increase in the broad-scale documented range of alien plants in SAPIA. Several species (Campuloclinium macrocephalum, Parthenium hysterophorus, Opuntia engelmannii, Cryptostegia grandiflora, Pennisetum setaceum, Tecoma stans, Sagittaria platyphylla, Gleditsia triacanthos, and Trichocereus spachianus) were considered to be of particular concern as they had increased substantially in distribution over the past decade. Henderson and Wilson (2017) reported further that approximately 126 taxa were targeted for clearing by the Department of Environmental Affairs' Natural Resource Management (NRM) programmes (formerly "Working for Water") between 2000 and 2012, although most effort was focussed on a relatively small number of widespread taxa (Table 21.1). Examination of the data suggested that whether a species was targeted for control or not made little difference, as both targeted and neglected species continued to spread at comparable rates. Henderson and Wilson (2017) concluded that this outcome was perhaps not surprising, given the lack of evidence of a general strategic approach to NRM's activities, and the absence of dedicated strategic efforts to contain specific invasive plants, or to reduce the rate at which they invade particular areas. By contrast, they found a clear signal that biological control had reduced rates of spread of several important invasive alien plant species. Notably, however, SAPIA was not designed as a tool to monitor management effectiveness, but rather as a means of collating information on alien plant distributions and how that distribution has changed over time. For reliable assessments of management efficacy over time, SAPIA would need to be augmented by monitoring specifically designed for this purpose. There have been few examples of such monitoring to date.

A species-specific study on the integrated control of Hakea sericea (Sweet Hakea) was conducted in the Western Cape by Esler et al. (2010). The control included a combination of felling and burning, augmented by biological control (van Wilgen et al. 1992). Data from two surveys, 22 years apart, suggested that the distribution of the species was reduced by $64 \%$, from $\sim 530,000$ to $\sim 190,000$ ha between 1979 and 2001. The species either decreased in density, or was eliminated from 492,113 ha, while it increased in density, or colonised 107,192 ha. It was concluded that the initial mechanical clearing, integrated with the judicious use of prescribed burning, in the 1970s and 1980s by the then Department of Forestry (van Wilgen et al. 1992) was responsible for reducing the density and extent of infestations, and that biological control was largely responsible for the failure of the species to re-colonise cleared sites, or to spread to new areas following unplanned wildfires 
(Hill et al. 2020b, Chap. 19, Sect. 19.3). Between 2000 and 2015, H. sericea increased its occurrence in quarter degree grid cells from 77 to 85 , an increase of $10 \%$ (Henderson and Wilson 2017). During the same period, the ecologically similar pine trees [Pinus pinaster (Cluster Pine) and P. radiata (Monterey Pine), for which no biological control is available] increased from 85 to 108 , and from 70 to 95 QDGCs, or $27 \%$ and $21 \%$ respectively.

Marais et al. (2004) reported that good progress had been made with clearing certain species (at a cost of ZAR 2.3 billion between 1996 and 2004, costs unadjusted for inflation), but also that at current estimated rates of clearing, many of the targeted species would not be brought under control within the next half century. They stressed that their estimates were preliminary, given the incomplete data on the project management system. In 2012, van Wilgen et al. (2012) reported that control operations were in many cases only applied to a relatively small portion of the estimated invaded area (2-5\% depending on the species), despite substantial spending (ZAR 3.2 billion in 2012 values).

\subsection{The Effectiveness of Management in Selected Areas}

\subsubsection{Monitoring of Control Effectiveness}

The effectiveness of control measures in a particular area (for example a protected area, a catchment area, a farm, or a stretch of river) needs to be assessed against the goal of the management, with such assessments based on regular monitoring of outcomes. However, while almost all alien plant control projects in South Africa have an implicit goal of reaching a "maintenance level", this goal is seldom stated explicitly in terms of the desired final extent or density of invasion (van Wilgen et al. 2016; Fill et al. 2017). The concept of a maintenance level recognises that, for most invasions, eradication is infeasible, but that invasions can be reduced to a level where the negative impacts are negligible and control costs are relatively low in perpetuity. In the vast majority of South Africa's government-funded alien plant control projects, the indicators used to monitor progress and set targets include the amounts of money to be spent, the number of people to be employed, and the areas to be treated. These are input or output indicators, rather than outcomes in terms of changes in the levels of plant invasions (Wilson et al. 2018). In the absence of a monitoring programme that is focussed on outcomes, it is difficult to assess effectiveness objectively. However, several studies have been conducted, particularly over the past decade, in which the effectiveness of management has been assessed, and these are summarised here. These studies provide a limited basis from which to derive broad conclusions about the effectiveness of control measures. 


\subsubsection{Alien Plant Control Projects in the Cape Floristic Region}

Most studies addressing the effectiveness of alien plant control measures in South Africa have been carried out in the Cape Floristic Region (CFR) in the Western and Eastern Cape provinces. The natural vegetation of the CFR comprises fynbos shrublands, and the most prominent invasive species are trees and shrubs (Australian Acacia, Hakea, and Pinus species in particular). Historical costs for control in CFR protected areas between 1996 and 2015 amounted to ZAR 564 million (2015 values; van Wilgen et al. 2016), additional amounts spent outside of formally protected areas. When assessed at the scale of individual projects, there is clear evidence that progress has been made. Macdonald et al. (1989) recorded marked declines in cover of all alien species in the Cape of Good Hope Nature Reserve following the implementation of a systematic clearing plan in the 1970s. Similar declines were recorded in the Berg River catchment (Fill et al. 2017; Fig. 21.2), the Vergelegen Estate (van Rensburg et al. 2017; Fig. 21.3), and along the Rondegat River (Fill et al. 2018, see Sect. 21.9). In the Hawequas mountains, where control focussed on the removal of abandoned pine plantations, McConnachie et al. (2016) estimated that the cover of invasive trees would have been almost $50 \%$ higher had there been no control. They also concluded that control might have prevented a larger area from being invaded if it had focussed all of its effort on untransformed land, and not on abandoned plantations. However, the costs associated with many of these projects were much higher than originally estimated. McConnachie et al. (2012) concluded that the cost to clear the Krom and Kouga

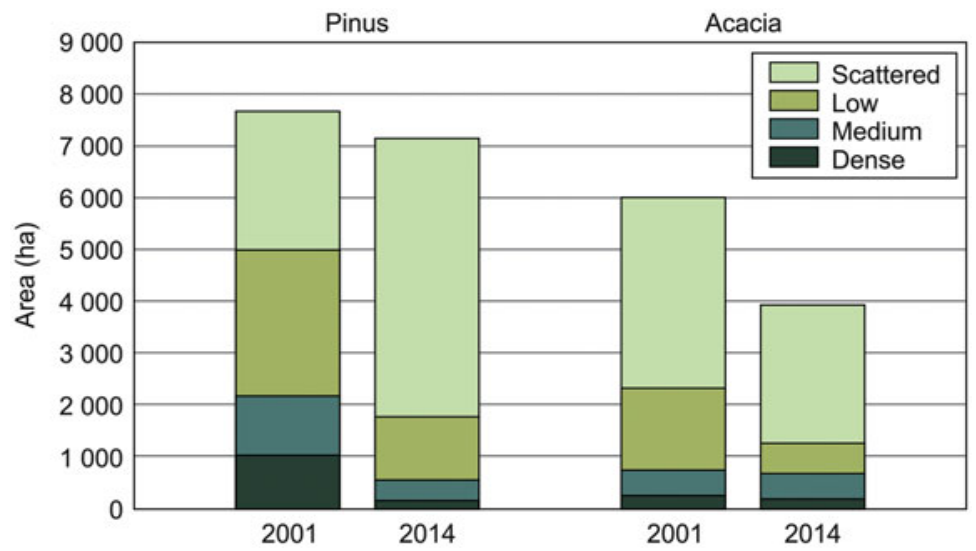

Fig. 21.2 Area occupied by alien Pinus and Acacia trees at different levels of cover in the upper Berg River catchment at the initiation of a control project in 2001, and after 13 years of treatments in 2014. Cover levels are dense ( $>50 \%$ cover), medium (26-50\% cover), low (6-25\% cover) and scattered $(0.5-5 \%$ cover). Figure redrawn from Fill et al. (2017) with permission 


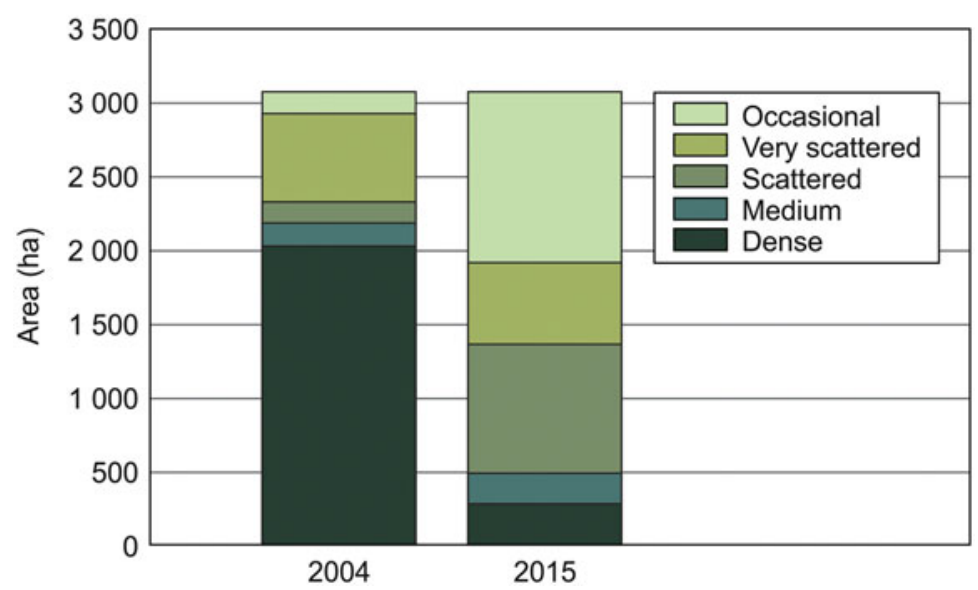

Fig. 21.3 Area occupied by invasive plants in six cover classes at Vergelegen Wine Estates in 2004 and 2015 . The classes are occasional $(<1 \%$ cover); very scattered $(1-5 \%$ cover $)$; scattered $(5-25 \%$ cover); medium ( $25-50 \%$ cover); dense ( $50-75 \%$ cover); and closed ( $>75 \%$ cover). Figure redrawn from van Rensburg et al. (2017) with permission

catchments in the Eastern Cape was 2.4 times higher than the highest equivalent estimate made elsewhere in South Africa at the time. The cost to clear the Berg River catchment was estimated at ZAR 6 million in 1996 (2016ZAR values; van Wilgen et al. 1997), but by 2016 the actual cost had reached ZAR 50 million (2016 ZAR values), 8.3 times the original estimate, without having reached a maintenance phase (Fill et al. 2017). Similarly, on privately-owned land at Vergelegen Estate, operations cost 3.6 times more than was originally estimated (ZAR 43.6 vs. 12.19 million respectively; van Rensburg et al. 2017). Much of this problem can be attributed to regular unplanned wildfires which necessitate large amounts of follow-up to clear seedlings that appear in dense stands after wildfires. However, in some cases, the additional costs may well be due to management inefficiencies. For example, McConnachie et al. (2012) found significant inefficiencies in the Krom and Kouga catchments, in the form of inaccurate records, where $25 \%$ of the areas recorded as having been cleared had in fact not been cleared; and Kraaij et al. (2017) found that the quality of many treatments in the Garden Route National Park was inadequate, with work done to standard in only $23 \%$ of the assessed area. The prognosis for gaining control of alien plant invasions in the CFR's protected area network was investigated by van Wilgen et al. (2016). The study concluded that, for scenarios in which control measures continued against all invasive plant species, the estimated required funding to achieve the goal of reducing invasions to a manageable level was up to 4.6 times greater than the amount spent over the past 20 years. Under many plausible future scenarios (for example $8 \%$ spread and current or reduced funding) the invaded area would continue to grow. 


\subsubsection{Management of Prosopis Species in the Northern Cape}

Trees in the genus Prosopis (Mesquite) were introduced to provide a source of fodder for livestock in the arid areas of South Africa, and subsequently became invasive. Historical estimates for the rate of spread of Prosopis trees in South Africa ranged from 3.5 to $18 \%$ per year (van den Berg 2010; Wise et al. 2012), which implied that the invaded area could double every $5-8$ years. In the Northern Cape, the estimated total invaded area increased by almost a million hectares between 2002 and 2007, which is equivalent to $27.5 \%$ per year, and this occurred at a time during which ZAR 390 million (2012 values) was spent on control (van Wilgen et al. 2012). A more recent update (RT Shackleton unpubl. data) found that the public works clearing projects had treated 203,000 ha of the area invaded by Prosopis between 2000 and 2015. Each site also received on average 2.7 follow up clearings. The cost of these measures amounted to ZAR 1.8 billion (unadjusted for inflation) over the same period. The project started in 1995, but cost estimates prior to the year 2000 are not available. Between 2000 and 2016, Prosopis glandulosa (Mesquite), and Prosopis hybrids increased their range from 40 to 112, and 390 to 481 quarterdegree grid cells, increases of $180 \%$ and $23 \%$ respectively (Henderson and Wilson 2017), suggesting that control is doing little to stop the spread of these trees.

\subsubsection{Invasive Plant Control in the Kruger National Park (Mpumalanga and Limpopo Provinces)}

Van Wilgen et al. (2017) provided a recent review of alien plant control in the Kruger National Park (KNP). There have been attempts at control in the KNP since the mid-1950s, but in the late 1990s these attempts were broadened, and between 1997 and 2016, over ZAR 300 million was spent on invasive alien plant control. Good progress was made with the control of several species, notably Sesbania punicea (Red Sesbania), Opuntia stricta (Australian Pest Pear), Lantana camara (Lantana) and two species of invasive alien aquatic plants. In all of these cases, progress with reducing populations of the invasive species was due to biological control. Nonetheless, much effort was also directed towards species that were subsequently recognised as being of lower priority. For example, $38 \%$ of available funds was spent on alien annuals between 1997 and 2016. Funds were sometimes directed towards these annuals to meet the goals of employment creation in areas where priority species were not present. The absence of documented assessments of the potential impact of various species also allowed managers to base their decisions on perceptions of the relative impact of candidate species. In addition, because management goals were focussed on inputs (funds disbursed, employment created) 
or outputs (area treated), there was a lack of monitoring the ecological outcomes of control operations.

\subsubsection{Control of Chromolaena odorata in the Hluhluwe- iMfolozi Park, KwaZulu-Natal}

In 1978, managers of the 90,000 ha Hluhluwe-iMfolozi Park (HiP) in KwaZuluNatal first noticed the presence of the alien shrub Chromolaena odorata (Triffid Weed). By 2003, this species had increased in extent and covered almost half of the HiP (Dew et al. 2017). A concerted control programme was then implemented at a cost of ZAR 103 million, and by 2011 the invasions were reduced to acceptably low levels (Fig. 21.4). The success came about because the management team applied several aspects of best practice, including a dedicated "rapid response" team, the integration of fire and mechanical clearing, a focus on areas of low infestation, flexibility with regard to the deployment of teams, regular monitoring and generous funding. In addition, te Beest et al. (2017) reported that "the team was only paid following completion of a contract and after a thorough inspection of the quality of the work by the Project Manager". Many other control projects in South Africa unfortunately did not incorporate these features, and this may well account for the differences in success. This programme essentially focussed on a single species, and the control of other invasive taxa in the HiP was not documented.

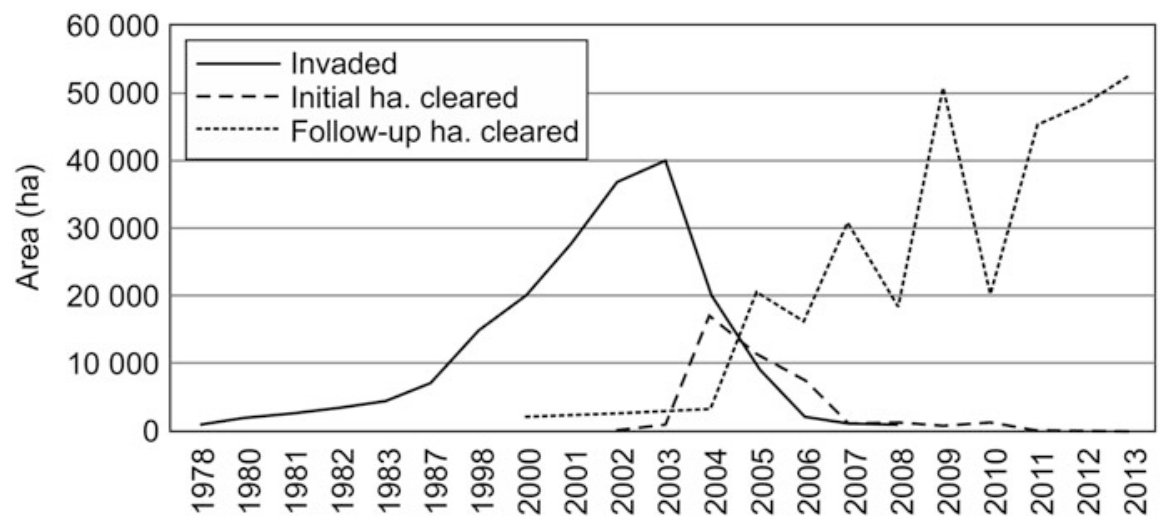

Fig. 21.4 Area invaded by Chromolaena odorata (Triffid Weed) in Hluhluwe-iMfolozi Park, and areas cleared and followed up between 2000 and 2013. Figure redrawn from te Beest et al. (2017) with permission 


\subsection{Managing Conflict Species}

\subsubsection{Conflict Species in South Africa}

Conflict-generating invasive alien species are defined as species that have relatively high value for some people, while at the same time being capable of invading natural vegetation and generating high levels of negative impact (van Wilgen and Richardson 2014; Zengeya et al. 2017). There are several prominent examples of such species in South Africa (Table 21.2). The management of species that fall into this category is complicated because opposing value systems have to be accommodated. In South Africa, this issue has been addressed in a number of ways, discussed in the sections below.

\subsubsection{Catering for Conflict Species in Regulations}

Species listed as invasive in South Africa's A\&IS Regulations have to be controlled, and may not be cultivated or traded. However, permits will be granted for some species (listed as Category 2) that have commercial value. These can be cultivated and traded under permit, but the permit-holder can be held liable for spread of the species. Some listed invasive species may be exempted from control requirements if there are many individual plants that have significant ornamental value (Category 3 ). These individual plants may be retained (e.g. in gardens), but may not be further cultivated, traded, or replanted (i.e. the species are phased out rather than attempting to actively remove them from private property). It is currently unclear whether or not these regulatory approaches are effective (van Wilgen and Wilson 2018).

\subsubsection{Using Biological Control Agents to Reduce Seed Output}

Proposals for the control of invasive Australian Acacia species were initially strongly resisted by the wattle industry (Stubbings 1977). Ecologists working in the field of biological control subsequently proposed the use of seed-feeding and gall-forming agents for these trees, and these were released following protracted negotiations with representatives of the wattle industry. These agents have been markedly successful in reducing seed output (Moran and Hoffmann 2012), and have substantially slowed the spread of these species in many areas (Henderson and Wilson 2017; Hill et al. 2020b, Chap. 19). 


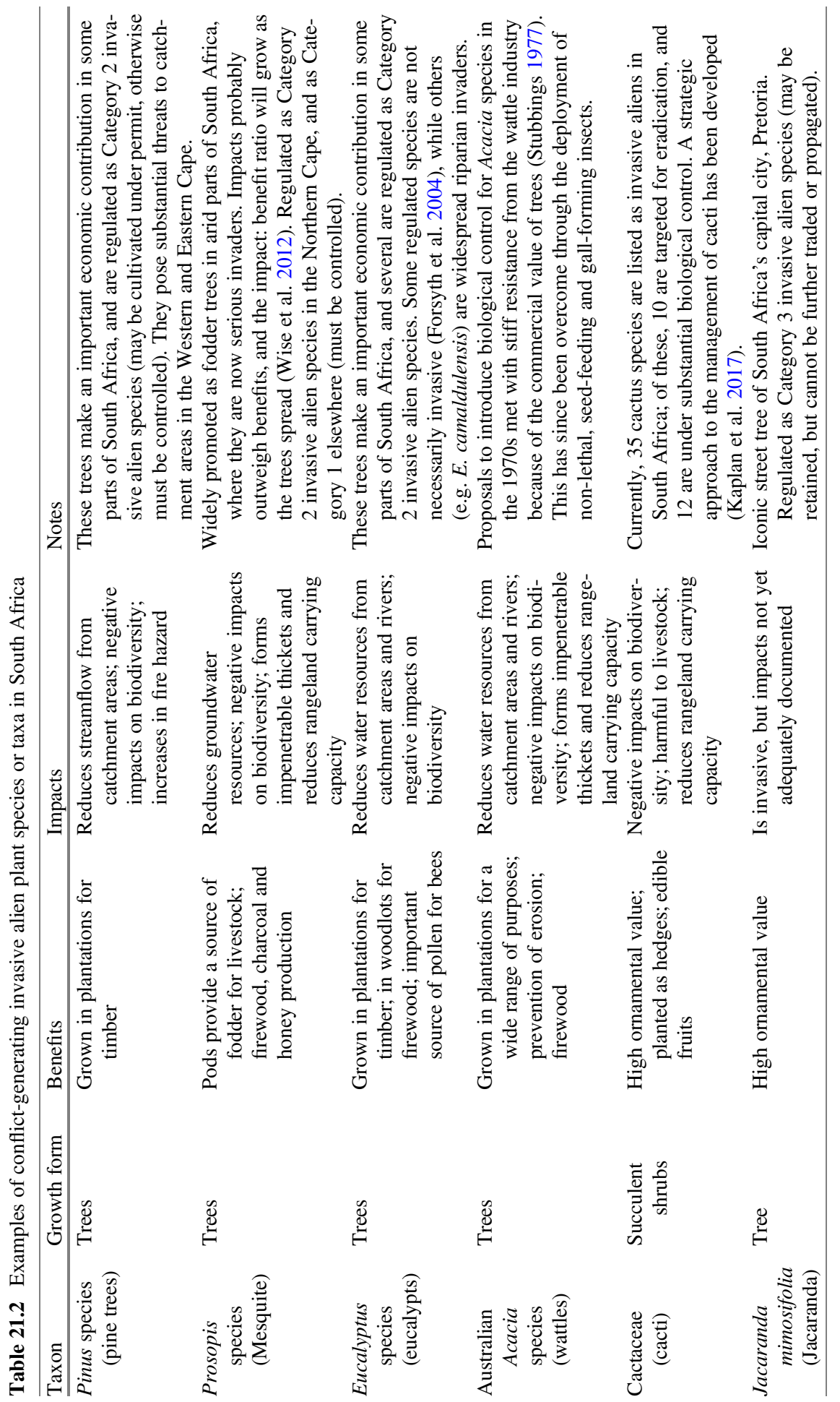




\subsubsection{Using Sterile Cultivars}

The use of sterile cultivars (for example in the case of Pinus and Australian Acacia species used in commercial forestry) is sometimes proposed as a solution to the problem of invasions that originate from commercial plantations, but there are no documented cases of where this has been successful in South Africa. It has also been shown that large reductions in fecundity do not necessarily adequately reduce the population growth rates of long-lived species, which remain an invasion threat (Knight et al. 2011). In addition, while modern technologies such as genetic modification may be used to develop sterile varieties (Miao et al. 2012), forestry companies stand to lose environmental certification status as certifying bodies prohibit the use of genetically modified organisms (van Wilgen and Richardson 2012). Similarly, the use of sterile cultivars of horticultural species has been proposed as a means of reducing conflicts. There are, however, still several open research questions as to the nature and stability of sterility required to sufficiently reduce the risk, and whether sterility on its own would be sufficient to prevent invasions (Richardson and Petit 2005).

\subsection{Returns on Investment from Control Measures}

The economic costs of plant invasions, and the economic benefits of control, have also been the subject of a few studies in South Africa. One study (De Lange and van Wilgen 2010) suggested that the cost of some impacts (lost water, grazing and biodiversity) was currently about ZAR 6.5 billion per annum, but would become much higher as invasions grow. In the case of biological control of invasive plants, all studies have estimated very high returns on investment. By comparing the costs of biological control research and implementation to the benefits of restored ecosystem services, or avoided ecosystem degradation, and avoided ongoing control costs, biological control was shown to be extremely economically benefitial, with estimated benefit:cost ratios ranging from 8:1 up to 3726:1 (van Wilgen and De Lange 2011).

To estimate a return on investment from mechanical and chemical alien plant control measures, it would be necessary to know both the historic cost of control, and the value of impacts avoided due to control. There are no reliable estimates of the value of impacts avoided due to control. It is well known, though, that the cost per unit area to control an invasion rises exponentially as the density of the invasion increases (Marais et al. 2004). If invasions can be contained while they still occupy a smaller area, at relatively low densities, returns on investment from control operations should be positive. At some point, as yet unquantified, the cost of effective control would exceed the cost of the impact, and attempts to mechanically or chemically control invasions at this stage would deliver negative returns on investment (Fig. 21.5). More research is needed on this aspect to gain a better understanding. 


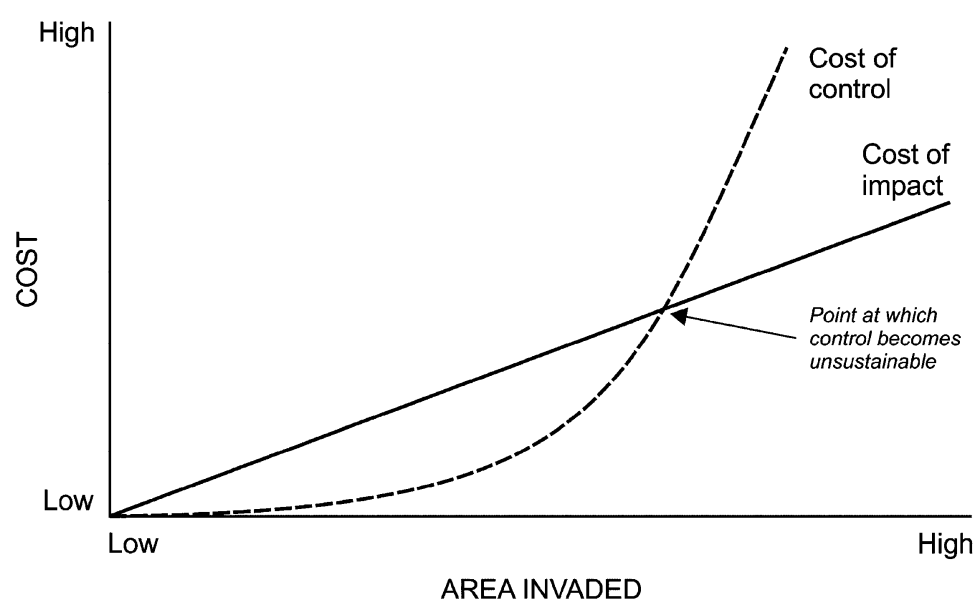

Fig. 21.5 Hypothetical representation of increases in the costs of impact, and the costs of control, associated with alien tree invasions. The cost of control increases exponentially as the invaded area and the density and size of trees increase. Control becomes economically unsustainable at the point at which the costs of control are exceeded by the costs suffered as a result of invasion (From van Wilgen and Richardson 2014). There are, of course, many other potential forms of these relationships - impact is often negligible at low densities, but rises exponentially once a threshold has been passed, while there are often fixed costs to controlling an area (related e.g. to issues of access and the minimum size of a control team). Of particular concern is that in general by the time an invasion has very obvious impacts, the cost of control is already several fold greater than the cost of pre-emptive management. If control costs vastly exceed impact costs (as per the far right of the graph), it has been proposed that control should not be attempted, and focus should rather be placed on deriving benefits from such "novel ecosystems". There are, however, various criticisms of this concept, e.g. that it might encourage managers to give up when it would be preferable to implement control

There have been mixed findings regarding returns on investment from alien plant control projects. In a cost-benefit analysis of six sites in the Eastern Cape, Hosking and Du Preez (2004) concluded that "catchment management on all the sites carried out by the Working for Water Programme is inefficient"; benefit:cost ratios ranged between 0.03 and 0.75 , indicating negative returns on investment, although though the benefits of associated employment creation were not included. By modelling the spread of alien plants and their effects on water runoff, with and without attempts at control, in the Western Cape's Berg River catchment, van Wilgen et al. (1997) concluded that such control would be "effective and efficient". The estimated delivery cost of water, with and without the management of alien plants, was 57 and $59 \mathrm{c} \mathrm{kl}^{-1}$ respectively. The projected clearing costs used in arriving at this estimate were around ZAR 180,000 per year for initial clearing over 10 years, followed by about ZAR 25,000 per year for maintenance thereafter (1997 ZAR values). The actual costs eventually amounted to almost ZAR 50 million by 2015 (2015 ZAR; 8.3 times greater than the net present value of costs estimated in 1997, Fill et al. 2017). Despite considerable reductions in the cover of alien plants by 2015, the invasions were still present over much of the area, albeit at reduced densities. 
The outcome that was projected in 1997 had therefore not been realised, because control methods were not effectively applied, and because the control costs were underestimated (Fill et al. 2017).

Finally, the potential returns on investment from invasive plant control operations have been the subject of several recent studies that compared the outcomes of various management scenarios (Vundla et al. 2016; Mudavanhu et al. 2016; Morokong et al. 2016; Nkambule et al. 2017). The scenarios included different rates of spread, included or excluded value-added products using biomass from invasive plants, and included or excluded private sector co-funding. The inclusion of co-funding and value-added products delivered more favourable returns on investment, and a failure to intervene at all would deliver negative outcomes. These operations could therefore be financially viable, but the accuracy of the predictions depends on whether or not the underlying assumptions will hold. These assumptions include that effective and professional clearing would continue into the future; that co-financing would be available; that due compensation for the services rendered and the value-added products produced would be realised; that the extent of the invasions was accurately known; and that the costs had been accurately estimated. Most, or even all, of the above assumptions will not hold, however, because alien plant invasions are rarely accurately mapped (see, for example, Cheney et al. 2018); the costs of control are routinely under-estimated by a factor of 3-7 times; there are low levels of efficiency associated with control work; and including value-added products could lead to unintended consequences. Consequently, there can only be a low level of confidence in these predictions of the return on investment from control projects.

\subsection{Synthesis}

There are a number of points that can be made with regard to the effectiveness of mechanical and chemical control measures. Firstly, as widespread invasions by alien plants can bring about substantial costs, it would obviously be beneficial to reduce invasions as far as possible. In South Africa, the largest proportion of funding for control operations comes from the Working for Water programme (WfW) within the Department of Environmental Affairs. Between 1995 and 2017, WfW spent ZAR 15 billion (unadjusted for inflation) on alien plant control, but this has only been enough to deal with between 2 and 5\% of the estimated extent of invasions each year, and so the most important invasive species continue to spread (van Wilgen et al. 2012; Henderson and Wilson 2017).

Control interventions have nonetheless succeeded in reducing the extent of invasions in some areas. Early work demonstrated that the systematic implementation of a careful plan resulted in the reduction of populations of invasive alien trees and shrubs to maintenance levels (Macdonald et al. 1989). Where concerted efforts have been made to remove invasive trees from fynbos catchment areas, marked declines in the density have been achieved (Fill et al. 2017; van Rensburg 
et al. 2017). One estimate (McConnachie et al. 2016) suggested that the invaded area in the fynbos-clad Hawequas mountains would have been almost $50 \%$ higher if control operations had not been carried out. Ongoing control has also reduced the extent of invasions of several species in savanna ecosystems, including Lantana camara, Opuntia stricta, and Chromolaena odorata (van Wilgen et al. 2017; Dew et al. 2017; te Beest et al. 2017). At several localised sites, therefore, control measures have been effective. The picture changes when progress is assessed at a national scale, however, because plant invasions have generally continued to grow, some substantially (Henderson and Wilson 2017). Meaningful progress in reducing widespread invasions to a maintenance level, therefore, can arguably only be made if the available funding is focused on priority sites and species (Box 21.2). Essentially, the conscious practice of conservation triage (Bottrill et al. 2008) will need to be introduced, and this will require agreement on which species, and which areas, to target for control. Because alien plants spread more rapidly than they are being removed, current control efforts could fail if funds are spread too thinly, as suggested by modelling exercises (Higgins et al. 1997; van Wilgen et al. 2016). If adequate funding were re-directed to agreed priority areas, then the chances of achieving control in those areas would increase. Similarly, by focussing on priority species, scarce funds could be concentrated where they would be most effective. For example, funding for the control of Pinus and Australian Acacia species in fynbos is divided equally between these two taxa (van Wilgen et al. 2016). Pinus species, however, will eventually cover a much larger area than Acacia species if allowed to spread. If funds were diverted from Acacia species (which are under more effective biological control) to Pinus, then the eventual outcome would be far more favourable. Although prioritisation studies have already been initiated (e.g. Forsyth et al. 2012), it is going to be challenging to get managers to accept the need for triage, because terminating projects where funds have already been expended will understandably meet with resistance (see also Foxcroft et al. 2020, Chap. 28, Sect. 28.7). In conclusion, the implementation of focused, well-funded and well-managed control measures should bring invasions down to a maintenance level in many priority areas. Such interventions should bring very attractive returns on investment, but they will require some fundamental changes to the current modus operandus.

\section{Box 21.2 Wisdom from the Past}

Alien plant control has been considered, and practiced, in South Africa for many decades. The question arises as to whether we can learn from this experience. Two quotes, in particular, seem relevant.

In his report on the conservation of the vegetation of the Cape Floristic Region, Prof. C.L. Wicht noted that "it seems, at present, that unless enormous sums of money are expended on their [invasive alien plant] eradication or control they will become dominant everywhere except in nature reserves and other selected areas where they will constantly be destroyed" 
Box 21.2 (continued)

(Wicht 1945). There are two important aspects to this quote. First, there was an assumption that attempts to bring alien plant invasions down to maintenance levels would focus only on protected areas, and second, that a focus on protected areas would be the only way in which at least a representative portion of the unique Cape vegetation could be retained. In essence, this was an early call for the need to practice conservation triage. This concept (whereby some invaded land is abandoned to invasions, with control focussing on areas where progress can be made) has recently re-emerged (Bottrill et al. 2008; van Wilgen et al. 2016), but is controversial.

In the 1970s, the Department of Forestry embarked on an ambitious campaign aimed at eliminating invasive alien Hakea shrubs from vast areas in the southwestern mountains of what was then the Cape Province. John Fenn, regional director of forestry in the Western Cape, noted in 1980 that " $B y$ using new methods and techniques, the brush-cutter became the most useful and effective machine for these operations. The costs of eradicating dense areas of Hakea dropped dramatically. Labour units used per hectare dropped from 22 to 5, and in certain areas, dropped as low as 1.5 units per hectare. All of a sudden the clearing of these vast areas of Hakea no longer looked impossible" (Fenn 1980). This is a clear indication that mechanised techniques are essential if the goals of reaching a maintenance level are to be achieved. However, the current practice of relying on manual and labour-intensive clearing (to maximise employment opportunities) has reduced efficiency levels, resulting in a lack of progress towards the goals of reaching a maintenance level (Fill et al. 2017).

Acknowledgements $\mathrm{BvW}$ and JRW thank the DSI-NRF Centre for Invasion Biology and the South African National Research Foundation for support (grants 109467, 85412 and 86894). LCF acknowledges South African National Parks, the DSI-NRF Centre for Invasion Biology, Stellenbosch University, and the National Research Foundation of South Africa (Grant Numbers IFR2010041400019 and IFR160215158271). The South African Department of Environment, Forestry, and Fisheries (DEFF) are thanked for funding the South African National Biodiversity Institute noting that this publication does not necessarily represent the views or opinions of DEFF or its employees.

\section{References}

Attwell J (1985) Alien plant control by volunteer groups in the fynbos biome. In: Macdonald IAW, Jarman ML, Beeston P (eds) Management of invasive alien plants in the fynbos biome. South African national scientific programmes report no. 111, CSIR, Pretoria

Bottrill MC, Joseph LN, Carwardine J et al (2008) Is conservation triage just smart decision making? Sci Soc 23:649-654. https://doi.org/10.1016/j.tree.2008.07.007 
Cheney C, Esler KJ, Foxcroft LC et al (2018) The impact of data precision on the effectiveness of alien plant control programmes: a case study from a protected area. Biol Invasions 20:3227-3241. https://doi.org/10.1007/s10530-018-1770-8

De Lange WJ, van Wilgen BW (2010) An economic assessment of the contribution of biological control to the management of invasive alien plants and to the protection of ecosystem services in South Africa. Biol Invasions 12:4113-4124. https://doi.org/10.1007/s10530-010-9811-y

Dew LA, Rozen-Rechels D, le Roux E et al (2017) Evaluating the efficacy of invasive plant control in response to ecological factors. S Afr J Bot 109:203-213. https://doi.org/10.1016/j.sajb.2016. 12.007

Erasmus DJ, Viljoen BD (1993) Screening and sequential application of herbicides for the control of Alhagi camelorum Fisch. Agricultural Research Council, Pretoria

Esler KJ, van Wilgen BW, te Roller KS et al (2010) A landscape-scale assessment of the long-term integrated control of an invasive shrub in South Africa. Biol Invasions 12:211-218. https://doi. org/10.1007/s10530-009-9443-2

Faulkner KT, Burness A, Byrne M et al (2020) South Africa's pathways of introduction and dispersal and how they have changed over time. In: van Wilgen BW, Measey J, Richardson DM, Wilson JR, Zengeya TA (eds) Biological invasions in South Africa. Springer, Berlin, pp 311-352. https://doi.org/10.1007/978-3-030-32394-3_12

Fenn JA (1980) Control of Hakea in the western Cape. In: Neser S, Cairns ALP (eds) Proceedings of the third national weeds conference of South Africa. Balkema, Cape Town, pp 167-173

Fill JM, Forsyth GG, Kritzinger-Klopper S et al (2017) An assessment of the effectiveness of a long-term ecosystem restoration project in a fynbos shrubland catchment in South Africa. J Environ Manag 185:1-10. https://doi.org/10.1016/j.jenvman.2016.10.053

Fill JM, Kritzinger-Klopper S, van Wilgen BW (2018) Challenges to the restoration of ecosystems through multiple alien species control: lessons from the Rondegat River, South Africa. Restor Ecol 26:434-438. https://doi.org/10.1111/rec.12585

Forsyth GG, Richardson DM, Brown PJ et al (2004) A rapid assessment of the invasive status of Eucalyptus species in two South African provinces. S Afr J Sci 100:75-77

Forsyth GG, Le Maitre DC, van Wilgen BW et al (2012) The prioritisation of invasive alien plant control projects using a multi-criteria decision model informed by stakeholder input and spatial data. J Environ Manag 103:51-57. https://doi.org/10.1016/j.jenvman.2012.01.034

Foxcroft LC, Freitag-Ronaldson S (2007) Seven decades of institutional learning: managing alien plant invasions in the Kruger National Park, South Africa. Oryx 41:160-167. https://doi.org/10. 1017/S0030605307001871

Foxcroft LC, Rouget M, Richardson DM et al (2004) Reconstructing 50 years of Opuntia stricta invasion in the Kruger National Park: environmental determinants and propagule pressure. Divers Distrib 10:427-437. https://doi.org/10.1111/j.1366-9516.2004.00117.x

Foxcroft LC, Richardson DM, Rouget M et al (2009) Patterns of alien plant distribution at multiple spatial scales in a large national park: implications for ecology, management and monitoring. Divers Distrib 15:367-378. https://doi.org/10.1111/j.1472-4642.2008.00544.x

Foxcroft LC, van Wilgen BW, Abrahams B, Esler KJ, Wannenburgh A (2020) Knowing-doing continuum or knowing-doing gap? Information flow between researchers and managers of biological invasions in South Africa. In: van Wilgen BW, Measey J, Richardson DM, Wilson JR, Zengeya TA (eds) Biological invasions in South Africa. Springer Berlin, pp 827-850. https://doi.org/10.1007/978-3-030-32394-3_28

Fugler SR (1983) The control of silky hakea in South Africa. Bothalia 14:977-980. https://doi.org/ 10.4102/abc.v14i3/4.1272

Greve M, von der Meden CEO, Janion-Scheepers C (2020) Biological invasions in South Africa's offshore sub-Antarctic territories. In: van Wilgen BW, Measey J, Richardson DM, Wilson JR, Zengeya TA (eds) Biological invasions in South Africa. Springer, Berlin, pp 205-226. https:// doi.org/10.1007/978-3-030-32394-3_8

Henderson L (2007) Invasive, naturalized and casual alien plants in southern Africa: a summary based on the Southern African Plant Invaders Atlas (SAPIA). Bothalia 37:215-248. https://doi. org/10.4102/abc.v37i2.322 
Henderson L, Wilson JRU (2017) Changes in the composition and distribution of alien plants in South Africa: an update from the Southern African Plant. Bothalia 47:a2172. https://doi.org/10. 4102/abc.v47i2.2172

Higgins SI, Turpie JK, Costanza R et al (1997) An ecological economic simulation model of mountain fynbos ecosystems-dynamics, valuation and management. Ecol Econ 22:155-169. https://doi.org/10.1016/S0921-8009(97)00575-2

Hill MP, Coetzee JA, Martin GD et al (2020a) Invasive alien aquatic plants in South African freshwater ecosystems. In: van Wilgen BW, Measey J, Richardson DM, Wilson JR, Zengeya TA (eds) Biological invasions in South Africa. Springer, Berlin, pp 95-112. https://doi.org/10. 1007/978-3-030-32394-3_4

Hill MP, Moran VC, Hoffmann JH et al (2020b) More than a century of biological control against invasive alien plants in South Africa: a synoptic view of what has been accomplished. In: van Wilgen BW, Measey J, Richardson DM, Wilson JR, Zengeya TA (eds) Biological invasions in South Africa. Springer, Berlin, pp 549-568. https://doi.org/10.1007/978-3-030-32394-3_19

Hosking SG, Du Preez M (2004) A cost-benefit analysis of the Working for Water Programme on selected sites in South Africa. Water SA 30:143-152. https://doi.org/10.4314/wsa.v30i2.5059

Jaca T, Mkhize V (2015) Distribution of Iris pseudacorus (Linnaeus, 1753) in South Africa. BioInvasions Rec 4:249-253. https://doi.org/10.3391/bir.2015.4.4.03

Jacobs LEO, Richardson DM, Wilson JRU (2014) Melaleuca parvistaminea Byrnes (Myrtaceae) in South Africa: invasion risk and feasibility of eradication. S Afr J Bot 94:24-32. https://doi.org/ 10.1016/j.sajb.2014.05.002

Jacobs LEO, Richardson DM, Lepschi BP et al (2017) Quantifying errors and omissions in the listing of alien species: Melaleuca in South Africa as a case study. NeoBiota 32:89-105. https:// doi.org/10.3897/neobiota.32.9842

Jooste WJ (1965) Experiments on the chemical control of Alhagi camelorum Fisch. S Afr J Agric Sci 8:287-288

Kaplan H, van Niekerk A, Le Roux JJ, Richardson DM, Wilson JRU (2014) Incorporating risk mapping at multiple spatial scales into eradication management plans. Biol Invasions 16:691-703. https://doi.org/10.1007/s10530-013-0611-z

Kaplan H, Wilson JRU, Klein H et al (2017) A proposed national strategic framework for the management of Cactaceae in South Africa The history and status of Cactaceae in South Africa. Bothalia 47:a2149. https://doi.org/10.4102/abc.v47i2.2149

Knight TM, Havens K, Vitt P (2011) Will the use of less fecund cultivars reduce the invasiveness of perennial plants? Bioscience 61:816-822. https://doi.org/10.1525/bio.2011.61.10.11

Kotzé JDF, Beukes BH, Newby TS, van den Berg EC (2010) National invasive alien plant survey. Council, Institute for Soil, Climate and Water, Report no. GW/A/2010/21, 1-17. Agricultural Research Council-Institute for Soil, Climate and Water, Pretoria

Kraaij T, Baard JA, Rikhotso DR, Cole NS, van Wilgen BW (2017) Assessing the effectiveness of invasive alien plant management in a large fynbos protected area. Bothalia 47:a2105. https://doi. org/10.4102/abc.v47i2.2105

Kumschick S, Foxcroft LC, Wilson JR (2020) Analysing the risks posed by biological invasions to South Africa. In: van Wilgen BW, Measey J, Richardson DM, Wilson JR, Zengeya TA (eds) Biological invasions in South Africa. Springer, Berlin, pp 569-592. https://doi.org/10.1007/ 978-3-030-32394-3_20

Le Maitre DC, Versfeld DB, Chapman RA (2000) The impact of invading alien plants on surface water resources in South Africa: a preliminary assessment. Water SA 26:397-408

Le Maitre DC, Forsyth GG, Wilson JRU (2015) Guidelines for the development of national speciesbased invasive alien management programmes: setting geographically differentiated goals. Report no. CSIR/NRE/ECOS/ER/2015/0030/A. Council for Scientific and Industrial Research, Stellenbosch

Lukey P, Hall J (2020) Biological invasion policy and legislation development and implementation in South Africa. In: van Wilgen BW, Measey J, Richardson DM, Wilson JR, Zengeya TA (eds) Biological invasions in South Africa. Springer, Berlin, pp 513-548. https://doi.org/10.1007/ 978-3-030-32394-3_18 
Macdonald IAW (2004) Recent research on alien plant invasions and their management in South Africa: a review of the inaugural research symposium of the Working for Water programme. S Afr J Sci 100:21-26

Macdonald IAW, Ashton ER et al (1985) The role of the volunteer group. In: Macdonald IAW, Jarman ML, Beeston PM (eds) Management of invasive alien plants in the fynbos biome. South African National Scientific Programmes report 111: 117-119. CSIR, Pretoria, pp 117-119

Macdonald IAW, Clark DL, Taylor HC (1989) The history and effects of alien plant control in the Cape of Good Hope Nature Reserve, 1941-1987. S Afr J Bot 55:56-75

Magona N, Richardson DM, Le Roux JJ et al (2018) Even well-studied groups of alien species might be poorly inventoried: Australian Acacia species in South Africa as a case study. NeoBiota 39:1-29

Marais C, van Wilgen BW, Stevens D (2004) The clearing of invasive alien plants in South Africa: a preliminary assessment of costs and progress. S Afr J Sci 100:97-103

McConnachie MM, Cowling RM, van Wilgen BW et al (2012) Evaluating the cost-effectiveness of invasive alien plant clearing: a case study from South Africa. Biol Conserv 155:128-135. https://doi.org/10.1016/j.biocon.2012.06.006

McConnachie M, van Wilgen BW, Gaertner M et al (2016) Using counterfactuals to evaluate the cost-effectiveness of controlling biological invasions. Ecol Appl 26:475-483. https://doi.org/10. $1890 / 15-0351$

Miao S, Li Y, Guo Q, Ding J et al (2012) Potential alternatives to classical biological control: using native agents in invaded habitats and genetically engineered sterile cultivars for invasive plant management. Tree For Sci Biotechnol 6:17-21

Moore JL, Runge MC, Webber BL et al (2011) Contain or eradicate? Optimizing the management goal for Australian acacia invasions in the face of uncertainty. Divers Distrib 17:1047-1059. https://doi.org/10.1111/j.1472-4642.2011.00809.x

Moran VC, Annecke DP (1979) Critical reviews of biological pest control in South Africa: 3. Jointed cactus, Opuntia aurantiaca Lindley. J Entomol Soc South Afr 42:299-329

Moran VC, Hoffmann JH (2012) Conservation of the fynbos biome in the Cape Floristic Region: the role of biological control in the management of invasive alien trees. BioControl 57:139-149. https://doi.org/10.1007/s10526-011-9403-5

Moran VC, Hoffmann JH, Zimmermann HG (2013) 100 years of biological control of invasive alien plants in South Africa: history, practice and achievements. S Afr J Sci 109(9/10):Art. \#a0022, 6 p. https://doi.org/10.1590/sajs.2013/a0022

Morokong $\mathrm{T}$ et al (2016) Clearing invasive alien plants as a cost-effective strategy for water catchment management: the case of the Olifants River Catchment, South Africa. S Afr J Econ Manag Sci 19:774-787. https://doi.org/10.4102/sajems.v19i5.1594

Mudavanhu S, Blignaut J, Nkambule N (2016) A cost-benefit analysis of using Rooikrans as biomass feedstock for electricity generation: a case study of the De Hoop Nature Reserve, South Africa. S Afr J Econ Manag Sci 19:788-813. https://doi.org/10.4102/sajems.v19i5.1602

Nkambule NP, Blignaut JN, Vundla T et al (2017) The benefits and costs of clearing invasive alien plants in northern Zululand, South Africa. Ecosyst Serv 27:203-223. https://doi.org/10.1016/j. ecoser.2017.04.011

Richardson DM, Petit R (2005) Pines as invasive aliens: outlook on transgenic pine plantations in the Southern Hemisphere. In: Williams CG (ed) Landscapes, genomics and transgenic conifers. Springer, Dordrecht, pp 169-188. https://doi.org/10.1007/1-4020-3869-0_10

Richardson DM, Foxcroft LC, Latombe G et al (2020) The biogeography of South African terrestrial plant invasions. In: van Wilgen BW, Measey J, Richardson DM, Wilson JR, Zengeya TA (eds) Biological invasions in South Africa. Springer, Berlin, pp 65-94. https://doi.org/10. 1007/978-3-030-32394-3_3

Riddin T, van Wyk E, Adams J (2016) The rise and fall of an invasive estuarine grass. S Afr J Bot 107:74-79. https://doi.org/10.1016/j.sajb.2016.07.008

Rouget M, Robertson MP, Wilson JRU et al (2016) Invasion debt—quantifying future biological invasions. Divers Distrib 22:445-456. https://doi.org/10.1111/ddi.12408 
Shackleton RT, Le Maitre DC, van Wilgen BW et al (2017) Towards a national strategy to optimise the management of a widespread invasive tree (Prosopis species; mesquite) in South Africa. Ecosyst Serv 27:242-252. https://doi.org/10.1016/j.ecoser.2016.11.022

Stubbings JA (1977) A case against controlling introduced acacias (ACACIA). S Afr For J 102:8-14

te Beest M, Howison O, Howison RA et al (2017) Successful control of the invasive shrub Chromolaena odorata in Hluhluwe-iMfolozi Park. In: JPGM C, Archibald S, Owen-Smith N (eds) Conserving Africa's mega-diversity in the Anthropocene: the Hluhluwe-iMfolozi Park story. Cambridge University Press, Cambridge, pp 358-382. https://doi.org/10.1017/ 9781139382793.020

Terblanche C, Kaplan H, Strathie LW et al (2016) An approach to the development of a national strategy for controlling invasive alien plant species: the case of Parthenium hysterophorus in South Africa. Bothalia 46:1-11. https://doi.org/10.4102/abc.v46i1.2053

van den Berg EC (2010) Detection, quantification and monitoring Prosopis spp. in the Northern Cape Province of South Africa using remote sensing and GIS. Masters Dissertation, North-West University, Potchefstroom

van Rensburg J, Richardson DM, van Wilgen BW (2017) The challenges of managing invasive alien plants on private land in the Cape Floristic Region: insights from Vergelegen Wine Estate (2004-2015). Trans R Soc S Afr 72:207-216. https://doi.org/10.1080/0035919X.2017.1288175

van Wilgen BW (2015) Plantation forestry and invasive pines in the Cape Floristic Region: towards conflict resolution. S Afr J Sci 111(7/8), Art. 114, 2 p. https://doi.org/10.17159/sajs.2015/a0114

van Wilgen BW, De Lange WJ (2011) The costs and benefits of biological control of invasive alien plants in South Africa. Afr Entomol 19:504-514. https://doi.org/10.4001/003.019.0228

van Wilgen BW, Richardson DM (2012) Three centuries of managing introduced conifers in South Africa: benefits, impacts, changing perceptions and conflict resolution. J Environ Manag 106:56-68. https://doi.org/10.1016/j.jenvman.2012.03.052

van Wilgen BW, Richardson DM (2014) Challenges and trade-offs in the management of invasive alien trees. Biol Invasions 16:721-734. https://doi.org/10.1007/s10530-013-0615-8

van Wilgen BW, Wannenburgh A (2016) Co-facilitating invasive species control, water conservation and poverty relief: achievements and challenges in South Africa's Working for Water programme. Curr Opin Environ Sustain 19:7-17. https://doi.org/10.1016/j.cosust.2015.08.012

van Wilgen BW, Wilson JR (eds) (2018) The status of biological invasions and their management in South Africa in 2017. South African National Biodiversity Institute, Kirstenbosch and DST-NRF Centre of Excellence for Invasion Biology, Stellenbosch

van Wilgen BW, Bond WJ, Richardson DM (1992) Ecosystem management. In: Cowling RM (ed) The ecology of fynbos: nutrients, fire and diversity. Oxford University Press, Cape Town, pp 345-371

van Wilgen BW, Little PR, Chapman RA et al (1997) The sustainable development of water resources: history, financial costs and benefits of alien plant control programmes. S Afr J Sci 93:404-411

van Wilgen BW, Dyer C, Hoffmann JH et al (2011) National-scale strategic approaches for managing introduced plants: insights from Australian acacias in South Africa. Divers Distrib 17:1060-1075. https://doi.org/10.1111/j.1472-4642.2011.00785.x

van Wilgen BW, Forsyth GG, Le Maitre DC et al (2012) An assessment of the effectiveness of a large, national-scale invasive alien plant control strategy in South Africa. Biol Conserv 148:28-38. https://doi.org/10.1016/j.biocon.2011.12.035

van Wilgen BW, Fill JM, Baard J et al (2016) Historical costs and projected future scenarios for the management of invasive alien plants in protected areas in the Cape Floristic Region. Biol Conserv 200:168-177. https://doi.org/10.1016/j.biocon.2016.06.008

van Wilgen BW, Fill JM, Govender N et al (2017) An assessment of the evolution, costs and effectiveness of alien plant control operations in Kruger National Park, South Africa. NeoBiota 35:35-59. https://doi.org/10.3897/neobiota.35.12391 
Versfeld DB, Le Maitre DC, Chapman RA (1998) Alien invading plants and water resources in South Africa: a preliminary assessment. WRC Report no. TT 99/98, Water Research Commission, Pretoria

Vundla T, Blignaut J, Nkambule $\mathrm{N}$ et al (2016) The opportunity cost of not utilising the woody invasive alien plant species in the Kouga, Krom and Baviaans catchments in South Africa. S Afr J Econ Manag Sci 19:774-787. https://doi.org/10.4102/sajems.v19i5.1603

Wasermann VD, Zimmermann HG, Neser S (1988) The weed silverleaf bitter apple ('Satansbos') (Solanum elaeagnifolium Cav.). Tech Comm 214. Department of Agriculture and Water Supply, Pretoria

Wicht CL (1945) Report of the committee on the preservation of the vegetation of the South Western Cape. Royal Society of South Africa, Cape Town

Wilson JRU, Gairifo C, Gibson MR et al (2011) Risk assessment, eradication, and biological control: global efforts to limit Australian acacia invasions. Divers Distrib 17:1030-1046. https:// doi.org/10.1111/j.1472-4642.2011.00815.x

Wilson JRU, Ivey P, Manyama P et al (2013) A new national unit for invasive species detection, assessment and eradication planning. S Afr J Sci 109(5/6), Art. \#0111, 13 p. https://doi.org/10. 1590/sajs.2013/20120111

Wilson JR, Panetta FD, Lindgren C (2017) Detecting and responding to alien plant incursions. Cambridge University Press, Cambridge. https://doi.org/10.1017/CBO9781316155318

Wilson JRU, Faulkner KT, Rahlao SJ et al (2018) Indicators for monitoring biological invasions at a national level. J Appl Ecol 55:2612-2620. https://doi.org/10.1111/1365-2664.13251

Wise RM, van Wilgen BW, Le Maitre DC (2012) Costs, benefits and management options for an invasive alien tree species: the case of mesquite in the Northern Cape, South Africa. J Arid Environ 84:80-90. https://doi.org/10.1016/j.jaridenv.2012.03.001

Zengeya T, Ivey P, Woodford DJ et al (2017) Managing conflict-generating invasive species in South Africa: challenges and trade-offs. Bothalia 47:a2160. https://doi.org/10.4102/abc.v47i2. 2160

Zenni RD, Wilson JRU, Le Roux JJ et al (2009) Evaluating the invasiveness of Acacia paradoxa in South Africa. S Afr J Bot 75:485-496. https://doi.org/10.1016/j.sajb.2009.04.001

Open Access This chapter is licensed under the terms of the Creative Commons Attribution 4.0 International License (http://creativecommons.org/licenses/by/4.0/), which permits use, sharing, adaptation, distribution and reproduction in any medium or format, as long as you give appropriate credit to the original author(s) and the source, provide a link to the Creative Commons licence and indicate if changes were made.

The images or other third party material in this chapter are included in the chapter's Creative Commons licence, unless indicated otherwise in a credit line to the material. If material is not included in the chapter's Creative Commons licence and your intended use is not permitted by statutory regulation or exceeds the permitted use, you will need to obtain permission directly from the copyright holder.

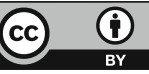

